\title{
Utilization of the YouTube Platform as a Distance Learning Media to Improve Mathematical Problem-Solving Ability in Elementary School
}

\author{
Ervin Dwi Kurniawan', Asep Bayu Dani Nandiyanto,", Tedi Kurniawan³, Muhammad \\ Roil Bilad ${ }^{4}$ \\ ${ }^{1}$ Departemen Pendidikan Ilmu Komputer, Universitas Pendidikan Indonesia, Indonesia \\ ${ }^{2}$ Departemen Pendidikan Kimia, Universitas Pendidikan Indonesia, Indonesia \\ ${ }^{3}$ Community College of Qatar, Qatar \\ ${ }^{4}$ Faculty of Integrated Technologies, Universiti Brunei Darussalam, Brunei Darussalam \\ *Corresponding author : nandiyanto@upi.edu
}

\begin{abstract}
Abstrak: Kemampuan siswa dalam belajar matematika khususnya dalam memecahkan masalah matematika cukup rendah. Kondisi pandemi memaksa pembelajaran jarak jauh sehingga menghambat peningkatan kemampuan siswa dalam menyelesaikan masalah matematis dan masalah non matematis. Inovasi dalam pembelajaran diperlukan untuk membantu siswa agar selalu termotivasi dalam belajar matematika. Penelitian ini bertujuan untuk mengetahui seberapa besar manfaat platform YouTube sebagai media pembelajaran jarak jauh untuk meningkatkan kemampuan siswa dalam menyelesaikan masalah secara matematis. Metode penelitian ini menggunakan pendekatan kuantitatif dengan target siswa kelas 5 SD. Hasil penelitian menunjukkan bahwa rata-rata post-test siswa adalah 83,4\%, meningkat 25,9\% dari hasil pre-test yang hanya mencapai 57.5\%. Hal ini menunjukkan bahwa video yang diunggah ke platform YouTube dapat menjadi cara yang efektif dan inovatif untuk meningkatkan kemampuan pemecahan masalah matematis siswa sekolah dasar.
\end{abstract}

Kata kunci: Pembelajaran jarak jauh, Pemecahan masalah, YouTube

\begin{abstract}
The ability of students to learn mathematics, especially in solving mathematical problems, is quite low. The pandemic conditions forced distance learning so that it hampered the improvement of students' ability to solve mathematical problems and non-mathematical problems. Innovation in learning is needed to help students to always be motivated in learning mathematics. This study aims to determine how much benefit the YouTube platform is as a distance learning medium to improve students' ability to solve problems mathematically. This activity method uses a quantitative approach with the target of grade 5 elementary school students. The results showed that the post-test average of students was $83.4 \%$, an increase of $25.9 \%$ from the pre-test results which only reached $57.5 \%$. This shows that videos uploaded to the YouTube platform can be an effective and innovative way to improve the mathematical problem-solving abilities of elementary school students.
\end{abstract}

Keywords: Distance learning, problem solving, YouTube 


\section{Introduction}

Learning is an interactive process between students and teachers who influence each other to achieve learning objectives. In learning students will carry out activities that aim to increase intelligence, knowledge, and change behavior (Arfani, 2018). In addition to creating experiences that will be fundamental in students' lives (Salam, 2017).

Learning mathematics is one that has a role to increase intelligence, knowledge, and change student behavior. Mathematics has also taught students to recognize and explain the problems that occur in students' daily lives. With mathematics too, students can learn and at the same time get solutions to solve problems that occur or are being observed (Mulyati, 2016).

Learning mathematics in elementary schools is not only to improve students' ability to count or apply formulas/procedures to solve common math problems, but also to improve students' ability to solve problems, including math problems and other problems that use mathematics to solve them (Mulyati, 2016). At the age of elementary school students 7 to 13 years, according to Piaget's cognitive theory is a concrete operational stage. Based on this cognitive development theory, children at primary school age generally have difficulty understanding abstract mathematics. Due to its abstract nature, mathematics is relatively difficult for elementary school students to understand (Mujiani, 2016). Therefore, appropriate methods and media are needed in the learning process to make it easier for students to understand the material.

In the current era of digitalization, the learning process can be done anywhere and anytime, therefore adaptive technology-based learning media is needed to facilitate the delivery of material (Wulandari et al., 2021).

Problem solving ability is very important in learning mathematics (Albay, 2019). In every school-level mathematics learning curriculum, there are always basic competencies related to mathematical problem solving (Akbar et al., 2017). The 2013 revised 2018 curriculum emphasizes that every learning in schools aims to improve problem solving abilities. In addition to the demands of the curriculum to develop problem-solving skills, it turns out that in the field many teachers are less focused on developing problem-solving abilities (Habibatul \& Azizah, 2019). This becomes one of the impetus to find out how the problem solving ability of students in elementary school.

Based on the observations, we found that the low student learning outcomes were due to the impact of online learning during the pandemic. This is because students have difficulty 
understanding the learning material. This distance learning process causes students' interest and focus to decrease and students become passive in learning so that it affects student scores (Cahyani et al., 2020). One of the challenges in the mathematics learning process faced by teachers is in delivering material because the learning process is carried out online. This can cause students' understanding of the learning material delivered to be less than optimal. In addition, in the online learning process, teachers are required to be proficient in operating technology. Which is used to help transition learning from face-to-face learning to virtual learning. Online learning that is carried out online is one solution to various problems related to students' cognitive learning outcomes (Jannah \& Nurdiyanti, 2021).

To deal with these problems, teachers must provide the right learning process by using interesting, educative and fun mathematics learning media (Wulandari et al., 2021). The selection of the right learning media will attract students' interest to carry out learning in a fun way, so that learning objectives can be achieved optimally.

There are various technology-based learning media that can be used in the distance learning process. There is WhatsApp, Google Classroom, Zoom Meeting, YouTube and many others. YouTube is an online video and the main purpose of this site is as a medium to search, view and share original videos to and from all corners of the world via a web (Wulandari et al., 2021). Of the several online learning media, YouTube learning media is one of the interesting media to be used as media choices when learning online. In YouTube media, teachers can present material content consisting of audio-visual. So that it can attract students' interest to listen to learning activities. In the current online learning system, YouTube-based media in the form of learning videos are very helpful in the learning process because they do not require meeting face-to-face in providing material to students. The way to make learning videos reach students, teachers only share a YouTube link to open so that students can easily access it.

This is in line with audio-visual media which will describe the steps of solving a problem in students' daily lives. So that learning like this is expected to be a vehicle for students to be more interested in learning mathematical problem solving skills in everyday life. This is relevant to activity that has been carried out that learning media has the same goal, namely better student abilities (Wulandari et al., 2021).

Problem solving is a student's effort to solve a problem, especially in mathematics. Problem solving in learning mathematics emphasizes the use of methods, procedures, and strategies that can be demonstrated systematically. In mathematics, the term problem solving 
refers to tasks that are given to improve students' understanding and ability in mathematics. (Rahmatiya et al., 2020). Problem solving can help students develop their mathematical concept understanding, connection, and communication skills (Albay, 2019). Students' problem-solving skills are important to improve cognitive skills and can motivate students to learn mathematics (Siswono, 2016). In addition, problem solving also encourages students to be able to use their own concepts and strategies to solve a given problem (Intaros et al., 2014). Problem solving can improve students' cognitive abilities (Bayat et al., 2010).

There are four problem solving steps compiled by Polya. Polya introduces models, procedures or steps in problem solving, namely: (1) understanding the problem; students need to identify in advance the information and what is being asked in the question; (2) draw up a plan; students connect knowledge that has been previously possessed with information and what is asked in the problem; (3) implement the plan; then students carry out calculations / computations; and (4) re-checking; students re-correct the results of problem solving that have been obtained (Zakiah et al., 2019).

Distance learning is learning using media that allows interaction between teachers and students. In distance learning between teachers and students are not face to face, in other words thanks to distance learning it is possible between teachers and students in different places, even very far from each other (Prawiyogi et al., 2020).

Distance learning or also called distance education is a training program for students or students who do not regularly meet in the same place to receive direct lessons from a teacher. Specific instructions and materials are sent or given to students, who will then perform tasks that will be assessed by the teacher. In practice, teachers and students can be separated not only geographically but also in time. (Prawiyogi et al., 2020).

In practice, there are several important factors that must be considered, so that the distance learning system can run well, namely attention, teacher confidence, experience, easy use of learning media, creative use of learning media, and interaction with students (Prawiyogi et al., 2020).

This study aims to see to what extent the use of learning media using videos uploaded to the YouTube platform can improve mathematical problem solving skills that will be implemented in mathematics subjects or in the daily lives of elementary school students. Using pre-experimental quantitative methods, this activity was conducted on 10 students as activity 
Jurnal Abdimas Kartika Wijayakusuma ISSN 2716-3512 (Online) ISSN 2721-0367 (Print)
This work is licensed under a Creative Commons Attribution-ShareAlike 4.0 International License.

samples with a one-group pre-test and post-test design containing 10 questions regarding the use of the YouTube platform and solving mathematical problems.

\section{Methods}

This activity was conducted as part of community service program with the aim of increasing student literacy. The activity took place in Ciwaruga 1 Elementary School Bandung, Indonesia. In this study, the literacy raised was numeraton literacy related to mathematical problem solving as in the targeted school there were mathematics subjects. This is in line with how this study leads to train one of problem-solving mathematical skills which close to the field of computer science or information technology.

As shown in Table 1, the activity method was carried out using a quantitative preexperimental approach (one-group pre-test post-test) on 10 students consist of 3 male students and 7 female students from the $5^{\text {th }}$ grade. The design of this study was arranged that the subject is given a pre-test, namely $\mathrm{A} 1, \mathrm{X}$ is the treatment carried out, then $\mathrm{A} 2$ is a post-test given after the subject was treated. (Rosdianto \& Murdani, 2017). Pre-test and post-test consist of 10 questions which are multiple choices.

Table 1. One-group pre-test post-test design.

\begin{tabular}{ccc}
\hline Pre-test & Treatment & Post-test \\
\hline $\mathrm{A}_{1}$ & $\mathrm{X}$ & $\mathrm{A}_{2}$ \\
\hline
\end{tabular}

\section{Results and Discussion}

A google form was created to find data related to the effectiveness of using the YouTube platform in math subjects as shown Fig. 1, whereas YouTube links for student learning media was shared through the WhatsApp Group as captured in Fig. 2.

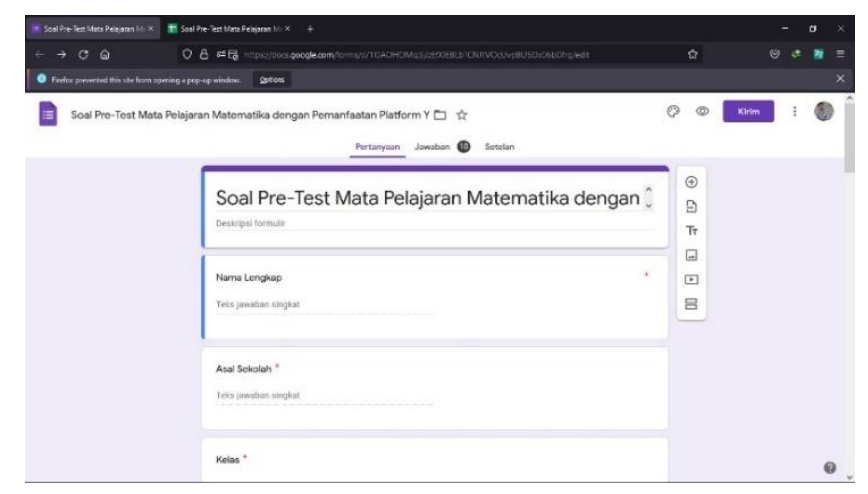

Fig. 1. Pre-test questions with google form. 


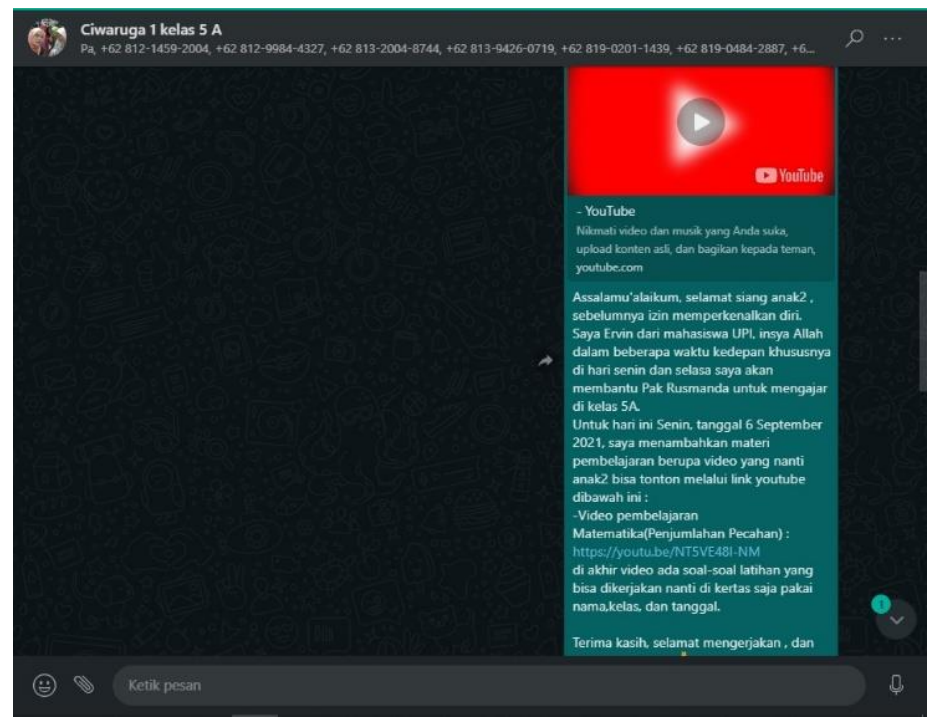

Fig. 2. Distribution of the YouTube link in the WhatsApp group.

Fig. 3 shows learning material of a math subject through the YouTube platform for 17 minutes and end with practice questions that must be done.

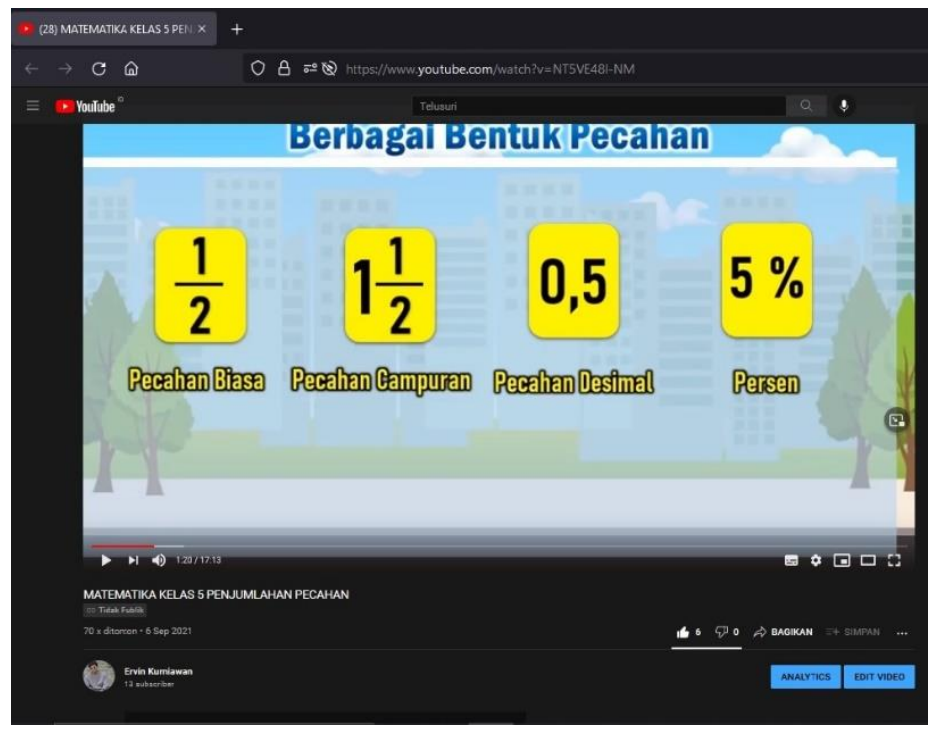

Fig. 3. Learning media on YouTube.

\subsection{Demography}

The activity was conducted at Ciwaruga 1 Elementary School, Bandung, Indonesia. Determination of the sample is carried out according to the class division that has been given by the principal, which is then selected $5^{\text {th }}$ grade to contribute as the activity sample. Of the 28 students who were asked to take part in the activity, only 10 were present when the activity 
took place. Consists of 3 male students and 7 female students. They part of generation $\mathrm{Z}$, who are actively using social media so they are familiar with YouTube platforms. Based on the teacher's explanation, they are active and sociable students, some are quite smart and diligent.

Based on it, no one has special problems so they don't mind taking part in this activity. Before the learning activity, we had a little discuss with the students. We saw that one male and three female students were very active, one of them gave their opinions regarding the purpose of this activity. The rest follow the activity but are inactive and turn off the webcam. We don't force them to turn on the camera because they might have signal problems.

\subsection{Pre-test and post-test result}

Table 2 describes the comparison of the results of pre-test and post-test scores based on the questions given. The pre-test questions are given before the students get the learning material, so the answers given are depending on students' limited knowledge. It is different with the post-test questions that are given after the respondents study independently related to mathematical problem solving by listening to learning materials through videos uploaded to YouTube platform. The post-test questions given are the same questions to be able to compare the value of students' knowledge before and after learning.

The basic questions asked in the pre-test and post-test questions lead to how students' knowledge regarding the YouTube platform, how to use YouTube as a learning media that is easier to understand, besides that there are also questions that lead to solving mathematical problems in everyday life as illustrated and explained in detail in the uploaded video.

The comparison is also illustrated as shown in Fig. 4. The graph clarifies the data in the tables. The graph shows the comparison between the average pre-test and post-test scores that have been carried out by students as also included in the table. Based on the direction, the straight line is towards the upper right which shows the increase of the average value. These two data presentations can be examined more clearly and the results discussed in the next section. 
Jurnal Abdimas Kartika Wijayakusuma ISSN 2716-3512 (Online) ISSN 2721-0367 (Print)
This work is licensed under a Creative Commons

Attribution-ShareAlike 4.0 International License.

CC BY SA

Table 2. Students' pre-test and post-test results.

\begin{tabular}{|c|c|c|c|c|}
\hline Number & Question & Pre-Test & Post-Test & Gain \\
\hline \multirow[t]{2}{*}{1.} & Do you know the & & & \\
\hline & YouTube platform? & $44.6 \%$ & $88.9 \%$ & $44.3 \%$ \\
\hline 2. & $\begin{array}{l}\text { Are you a YouTube } \\
\text { user? }\end{array}$ & $54.7 \%$ & $94.7 \%$ & $40 \%$ \\
\hline 3. & $\begin{array}{l}\text { Do you often use } \\
\text { YouTube? }\end{array}$ & $77.8 \%$ & $84.6 \%$ & $6.8 \%$ \\
\hline 4. & $\begin{array}{l}\text { Do you use YouTube to } \\
\text { study? }\end{array}$ & $57.8 \%$ & $87.8 \%$ & $30 \%$ \\
\hline 5. & $\begin{array}{l}\text { Did you learn about } \\
\text { mathematical problem } \\
\text { solving? }\end{array}$ & $74.6 \%$ & $77.8 \%$ & $3.2 \%$ \\
\hline 6. & $\begin{array}{l}\text { Have you ever solved a } \\
\text { problem } \\
\text { mathematically? }\end{array}$ & $47.8 \%$ & $77.8 \%$ & $30 \%$ \\
\hline 7. & $\begin{array}{l}\text { Rafi has Rp. } 30,000 \text { to } \\
\text { buy } 5 \text { Pencils at a price } \\
\text { of } 1 \text { pencil, which is Rp. } \\
2,500 \text {, then buys } 4 \\
\text { notebooks at a price of } 1 \\
\text { notebook for Rp. } 3,500 \text {, } \\
\text { so how much money } \\
\text { does Rafi have left after } \\
\text { buying } 5 \text { pencils and } 4 \\
\text { notebooks? } \\
\text { Can the above problems } \\
\text { be solved by solving } \\
\text { mathematical problems? }\end{array}$ & $67.8 \%$ & $100 \%$ & $32.2 \%$ \\
\hline 8. & $\begin{array}{l}\text { What is the result of the } \\
\text { above problem? } \\
5 \times 2500=12500 \\
4 \times 3500=14000 \\
30000-12500-14000 \\
=3500\end{array}$ & $58.9 \%$ & $74.6 \%$ & $15.7 \%$ \\
\hline 9. & $\begin{array}{l}\text { Can all problems be } \\
\text { solved by mathematical } \\
\text { problem solving? }\end{array}$ & $48.9 \%$ & $58.9 \%$ & $10 \%$ \\
\hline 10. & $\begin{array}{l}\text { Is solving problems } \\
\text { using mathematical } \\
\text { problem solving } \\
\text { important for everyday } \\
\text { life? }\end{array}$ & $44.6 \%$ & $88.9 \%$ & $44.3 \%$ \\
\hline
\end{tabular}


Jurnal Abdimas Kartika Wijayakusuma ISSN 2716-3512 (Online) ISSN 2721-0367 (Print)
This work is licensed under a Creative Commons Attribution-ShareAlike 4.0 International License.

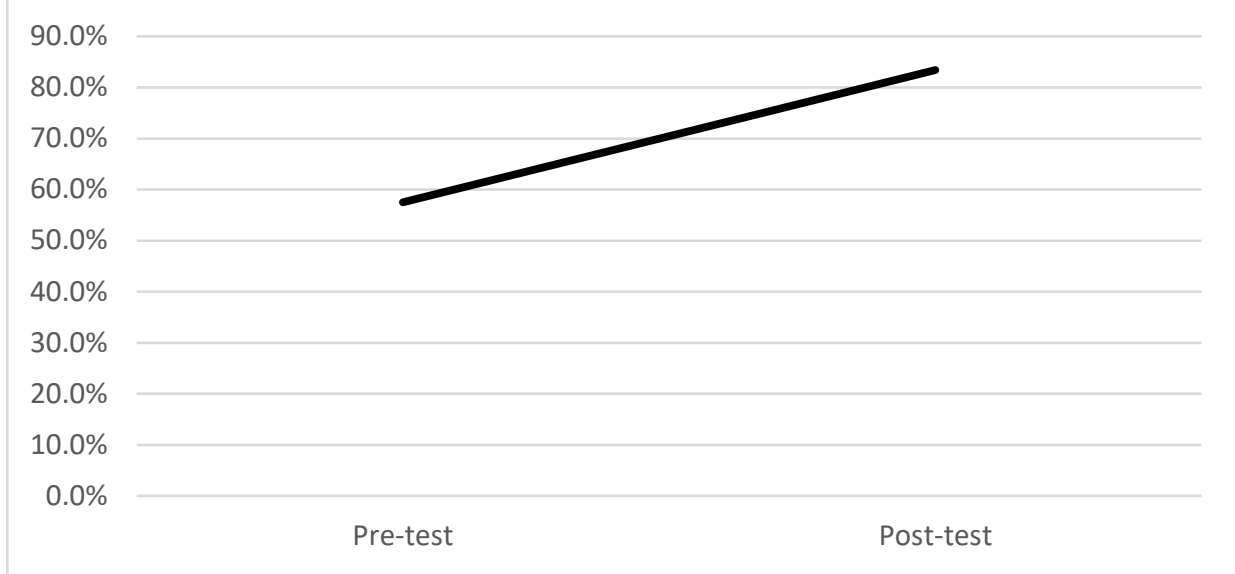

Fig. 4. The increased of average in pre-test and post-test result

\subsection{Discussion}

The discussion points from the results of the pre-test and post-test are as follows:

(i) Students' knowledge of general concepts of Mathematical problem solving increases, so that students are more familiar with what Mathematical problem solving is.

(ii) Students' reasoning and problem solving skills can be further trained as Mathematical problem solving is a competency that supports both skills.

(iii) Audio-visual media uploaded through the platform YouTube, can increase student motivation which leads to higher grades.

Results show the average ability and knowledge of students related to Mathematical problem solving as a whole when given pre-test questions is $57.5 \%$. After being given learning media content about mathematical problem-solving using YouTube media, the average number increased by $25.9 \%$ until becomes $83.4 \%$. With this increasing number, learning videos uploaded through the YouTube platform can be a learning media to train students' mathematical problem-solving skills. This is in line with activity on Ananda (2017) that learning materials by utilizing audio-visual media can increase student motivation which has implications for improving learning outcomes (Ananda, 2017).

\section{Conclusion}

Mathematical problem solving is an important competency possessed by students. With the help of digital technology, learning mathematical problem-solving skills can be done anytime and anywhere. The results showed that the results of the post-test of students increased 
by $25.9 \%$ to $83.4 \%$, as the results of the pre-test which only reached $57.5 \%$. This average increase shows that videos uploaded through the YouTube platform can be a learning media to train students' mathematical problem-solving skills in distance learning process.

\section{Acknowledgement}

We acknowledged Bangdos, Universitas Pendidikan Indonesia. We thank to Rusmanda, S.Pd. from Ciwaruga 1 Elementary School. This study is a part of community service (Program: community service program Tematik Literasi 2021 (26 August-26 Sept 2021) kel 21) Lembaga Penelitian dan Pengabdian Masyarakat (LPPM), Universitas Pendidikan Indonesia. We also thank to Kantor Jurnal dan Publikasi, Directorate of International Affairs, Universitas Pendidikan Indonesia. We thank to Anastasya Reskianissa, Muktiarni, S.Pd., M.Pd., and Rina Maryanti, S.Pd., M.Pd.

\section{References}

Akbar, P., Hamid, A., Bernard, M., \& Sugandi, A. I. 2017. Analisis kemampuan pemecahan masalah dan disposisi matematik siswa kelas xi sma putra juang dalam materi peluang. Jurnal Cendekia: Jurnal Pendidikan Matematika, 2(1), 144-153.

Albay, E. M. 2019. Analyzing the effects of the problem solving approach to the performance and attitude of first year university students. Social Sciences \& Humanities Open, 1(1), 129-142.

Ananda, R. 2017. Penggunaan media audio visual untuk meningkatkan hasil belajar pendidikan kewarganegaraan siswa kelas IV SD Negeri 016 Bangkinang Kota. Jurnal Basicedu, 1(1), 21-30.

Arfani, L. 2018. Mengurai hakikat pendidikan, belajar dan pembelajaran. Pelita Bangsa Pelestari Pancasila, 11(2), 88-100.

Bayat, S., \& Tarmizi, R. A. 2010. Assessing cognitive and metacognitive strategies during algebra problem solving among university students. Procedia-Social and Behavioral Sciences, 8(5), 403-410.

Danindra, L. S. 2020. Proses berpikir komputasi siswa SMP dalam memecahkan masalah pola bilangan ditinjau dari perbedaan jenis kelamin. Jurnal Ilmiah Pendidikan Matematika Volume, 9(1), 95-103.

Habibatul, I. K. \& Azizah, M. 2019. Analisis kemampuan penalaran siswa dalam pemecahan masalah matematika siswa kelas iv. Indonesian Journal of Educational Research and Review, 2(2), 210-218.

Hidayat, W. \& Sariningsih, R. 2018. Kemampuan pemecahan masalah matematis dan adversity quotient siswa SMP melalui pembelajaran open ended. JNPM (Jurnal Nasional Pendidikan Matematika), 2(1), 109-118. 
Intaros, P., Inprasitha, M. \& Srisawadi, N. 2014. Students' problem solving strategies in problem solving-mathematics classroom. Procedia - Social and Behavioral Sciences, 116, 4119-123.

Mujiani, D. 2016. Pengaruh media pembelajaran dan kecerdasan logis matematis terhadap hasil belajar matematika siswa. Jurnal Pendidikan Dasar UNJ, 7(2), 199-209.

Mulyati, T. 2016. Kemampuan pemecahan masalah matematis siswa sekolah dasar. EduHumaniora| Jurnal Pendidikan Dasar Kampus Cibiru, 3(2), 189-205.

Rahmatiya, R. \& Miatun, A. 2020. Analisis kemampuan pemecahan masalah matematis ditinjau dari resiliensi matematis siswa SMP.Teorema : Teori dan Riset Matematika, 5(2), 187-202.

Salam, R. 2017. Model pembelajaran inkuiri sosial dalam pembelajaran IPS. Harmony: Jurnal Pembelajaran IPS Dan PKN, 2(1), 7-12.

Prawiyogi, A. G., Purwanugraha, A., Fakhry, G. \& Firmansyah, M. 2020. Efektivitas pembelajaran jarak jauh terhadap pembelajaran siswa di SDIT cendekia Purwakarta. Jurnal Pendidikan Dasar, 11(1), 94-101.

Rosdianto, H., and Murdani, E. 2017. The implementation of POE (Predict Observe Explain) model to improve student's concept understanding on Newton's law. Jurnal Pendidikan Fisika, 6(1), 55-57.

Siswono, T. Y. E. 2016. Meningkatkan kemampuan berpikir kreatif siswa melalui pengajuan masalah matematika. Edumath, 1-10.

Wulandari, A. R., Masturi, M., \& Fakhriyah, F. 2021. Pengaruh media pembelajaran berbasis YouTube terhadap hasil belajar IPA siswa di sekolah dasar. Edukatif: Jurnal Ilmu Pendidikan, 3(6), 3782-3792.

Zakiah, N. E., Sunaryo, Y., \& Amam, A. 2019. Implementasi pendekatan kontekstual pada model pembelajaran berbasis masalah berdasarkan langkah-langkah polya. Teorema: Teori dan Riset Matematika, 4(2), 111-120.

Zayyadi, M., Supardi, L. \& Misriyana, S. 2017. Pemanfaatan teknologi komputer sebagai media pembelajaran pada guru matematika. Jurnal Pengabdian Masyarakat Borneo, 1(2), $25-35$. 